\title{
Slavonic Apocrypha: The Main Problems with Their Textual History (a Philological Perspective)
}

\author{
Liudmila Navtanovich
}

Universitat Autònoma de Barcelona, 2017SGR113

ludmila.n@mail.ru

\begin{abstract}
On one hand, Slavonic Apocrypha share the same characteristics with the other Old Slavonic Literature. But on the other, they had their own peculiarities in terms of the process of translating, editing and copying the text during its existence in Slavonic version.

Consequently, while some of the problems of their textual history ${ }^{1}$ might be common to the rest of the Slavonic Translated Literature, others are peculiar to themselves alone.

This paper presents certain problems that need to be resolved when reconstructing the textual history of a Slavonic Apocryphon. The resulting analysis is based on research into different Slavonic Apocrypha, among them the enigmatic 2 Enoch.
\end{abstract}

\section{Keywords}

Old Testament Pseudepigrapha - Slavonic Apocrypha - textual history - 2 Enoch

The first problem we have to tackle when dealing with a Slavonic Old Testament Apocryphon is what we call in Russian археограбическая работа: we have to discover all the copies we have of the text in question. And the problem is that the text is normally part of a codex, a collection of texts: those collections may be Chronographs or Collections of Old Testament Texts, or Collections of texts of a different nature (for example, eschatological texts), or they might be part of Paleia, etc.

1 The term textual history is commonly used in Slavistics, it's based on a fundamental study undertaken by D. Likhachev (Д.С. Лихачев, Текстология (X-XVII вв.), St Petersburg, 2001). 
And what is even more difficult, is that we need to find all the fragments of the Apocryphon we are studying. These fragments can be very short and may have been included in different texts, or in manuscripts of a composite nature (it is usually easier to find more or less "complete" copies of the Apocryphon, but it is much more difficult to discover all the "traces" of it "hidden" in other texts, and it can get even more complicated, because those texts may be both translated and originals).

And we never know where we should look for it (we might think of Paleia, Collections of Old Testament Texts, etc.), but in fact we might find a fragment of it in what we call деловая письменность (non-literary texts). One of the most striking examples of that can be found in 2 Enoch: the earliest fragment of it is preserved as part of Мерило Праведное (The Scales of Justice), and Мерило Праведное is an original text, not a translation, and it is a juridical text (what we usually call деловая письменность). ${ }^{2}$

That is on one hand; on the other hand, we can sometimes face another problem: since most of the Medieval Slavonic Texts were compilations, the Apocryphon that we are interested in might itself be of a composite nature. So we have to recognize all the parts of it and possibly the origins (sources) of each one.

Thus, one of the problems we have to tackle is to identify all the fragments the Apocryphon in question consists of. And different parts can have different sources. For instance, there is a not so well-known Slavonic Apocryphon called The Tale of Blessed Zorobabel, ${ }^{3}$ and it is a compilation, consisting of three parts. The first and longest part is the story of Zorobabel, which narrates events from the sixth century BCE (the plot in this part is a contest of wisdom between three of the bodyguards of Darius, king of Media. The first one tries to demonstrate the power of a king; the second one, the strength of wine; and the third, who is Zorobabel, the might of a woman, but above all the dominion of truth over everything. The story is known to be from LXX 1 Esdras 3-4. There is also a tale of Zorobabel (also known as Zerubbabel) in the Jewish Antiquities of Josephus and in the "Yosippon.") To discover the origin of the Slavonic text one should compare all those texts; in this case

2 Л.М. Навтанович, Лингвотекстологический анализ древнеславянского перевода Книги Еноха. Дисс. на соиск. уч. ст к.ф.н. St Petersburg, 2000, pp. 43-44.

3 L. Navtanovich, "The Slavonic Apocryphon of Zorobabel," in The Old Testament Apocrypha in the Slavonic Tradition. eds. L. DiTommaso and Chr. Boettrich, Tübingen, 2011, pp. 303336. Л.М. Навтанович, “Слово Блаженного Зоровавеля. Подготовка текста, перевод и комментарии," іn Библиотека Литературы Древней Руси, vol. 3, St Petersburg, 1999, pp. 150-159, 378-380. 
the source is the "Yosippon." ${ }^{4}$ However, our work is not over when we identify this source of the Apocryphon, because there are two more parts in The Tale ...

The second part describes events from the first century CE (the besieging and destruction of Jerusalem by Titus) and this part derives from the Old Russian Translation of Josephus's Jewish War. ${ }^{5}$

And there is even one more part. The third part tells of the courage of the Jerusalem warriors, and seems to have a different origin from the first two parts.

This final part of The Tale is very short. ${ }^{6}$

(110) Let you know, brothers, the power of God, the wrath of God on this city. (111) But what city was so strong, or had so many people, and such brave ones? (112) There is not such a strong and powerful city on the earth as Jerusalem! (113) There were twelve walls around the city, there lived such courageous people inside - one fought against one hundred, and entered a town without a battle. (114) Once, when Titus laid siege to the city, seven courageous [men] went forward and cut the troops into seven rows, they even reached Titus himself and nearly caught him in their hands, and returned safe.

(115) Let you know the strength, but even if you could move mountains, without God's help nothing is possible for people, and they will not be able to do anything without God's help. (116) Let you see, that people cannot do anything, but where there is a faithful king who teaches God's true law to his people, nobody will be able to conquer this city, even if it only has a few people; it is strong because of their faith.

(117) That was the end of the Captivity of Jerusalem.

It displays elements of folklore (e.g., (114) сєдмь Храврых вышєдше и на сеядмь оулиць) and some features from a literary tradition, such as a didactic nature and set expressions like (113) єдин на сто моужь выхождашшть, etc.

Its source has yet to be identified, but it coincides with the story from Tверская Летопись (Tver's Chronograph) attributed to the year $6880 .{ }^{7}$

\footnotetext{
4 Navtanovich, "The Slavonic Apocryphon of Zorobabel," pp. 304-312.

5 Ibid., pp. 312-313.

6 Ibid., p. 313 .

7 Полное собрание русских летописей. Рогожский летописеи, vol. 15.1, Petrograd, 1922, p. 103.
} 
To be honest, I identified another use of this fragment merely by chance: I was looking for the word "ulitsa" in the Dictionary by Sreznevski ${ }^{8}$ and I saw just the same phrase as an example from Тверская Летопись.

The fragment does not show any linguistic differences from the rest of the Tale, which, together with its origin from a literary text, makes its appearance in the apocryphon quite organic. The final phrase in the text is (117) то сицев

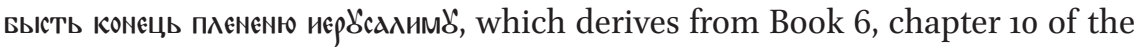
Jewish War.

So, while analysing a Slavonic Apocryphon we first have to discover the most ancient part of the text (the closest to the Urtext), while putting to one side fragments that might have other origins.

One of the important steps in reconstructing the history of an Apocryphon is to divide all the copies into the corresponding recensions and to define the links between the recensions (i.e. which one is primary, whether the other one(s) appeared in Slavonic or previously existed in other language(s) and had been translated from it/them, as well).

And here we also have certain problems. First of all: what do we understand by recension? If we understand recension to be (as D. Likhachev stated $)^{9}$ the result of conscious work by an editor (some kind of conscious editing process), then we may need to differentiate more recensions than we usually do. For example, when discussing 2 Enoch we tend to speak about the difference and the relationship between short and long recensions, but in fact each one of them can be divided at least into 2 "minor" ("secondary") recensions. ${ }^{10}$

An even more important question is the origin of the recensions when we talk about translated text as Apocrypha (and especially in cases when the original of the Slavonic Apocryphon is not preserved): did the recensions appear in

8 И.И. Срезневский, Материалы для словаря древнерусского языка по письменным памятникам, 4 vols., St Petersburg, 1893-1912.

9 Лихачев, Текстология.

10 Навтанович, Лингвотекстологический анализ, p. 36-77. Although the existence of 2 main recensions of 2 Enoch is generally accepted nowadays, there have been different opinions on the subject. For instance, one of the first scholars who studied the 'Slavonic Enoch', M.I. Sokolov, distinguished 3 recensions: a long one, an intermediary one and a short one; A. Vaillant wrote about 3 different recensions: a short one (primary one), the first revision (based on the short recension), the second revision (based on the long one - the first revision), F.Andersen proposed to differentiate 4 recensions: short and very short, long and very long, etc.: М. Соколов, Славянская Книга Еноха праведного, Part 2, Moscow, 1910, p. 98; A. Vaillant, Le livre des secrets d'Hénoch, Paris, 1952, pp. V-VIII; F.I. Andersen, "2 (Slavonic Apocalypse of) Enoch," in The Old Testament Pseudepigrapha. Apocalyptic literature and Testaments, vol. 1, New York, 1983, pp. 91-222, here p. 93. 
Slavonic or did they already exist in other language(s) (Greek, Hebrew, etc.)? For example, referring to 2 Enoch there is a long-term discussion of this question. ${ }^{11}$

What criteria can we use to demonstrate that the recension was produced in one language or another?

I would really like to explore this question in greater depth, because it does not seem to be given so much study as certain other questions on the textual history of the Slavonic texts.

I think that when talking about the number of possible translations we should base our thinking on not just one type of features, but perhaps on different types of peculiarities of the text which, when viewed all together, can speak for one or another origin of the text. So we could/should speak about a "cluster" of features.

Putting 2 Enoch as an example, I would just like to remind you that, as it's generally accepted, the apocryphon is preserved in 2 main recensions: short and long; and that among other problems, what is under discussion is whether the second recension appeared in Slavonic or whether it existed in another language (Greek supposedly, so we must have 2 different translations). ${ }^{12}$

One of the peculiarities of the Slavonic text of 2 Enoch is that while it is relatively short, it has a number of hapax legomena, or at least very rarely-used words (and it also contains certain words that are quite common in Slavic literary texts, but which in this particular text have obviously different meanings). And all these words are used in both recensions. It seems hardly possible that

2 Enoch has an enormous bibliography on this topic. Here is just an extremely brief commentary on possible opinions referring the relation between the recensions. In the first works on 2 Enoch the long recension was considered to be primary, after the study undertaken by A. Vaillant, the result of which was his critical edition of the text in 1952, the short recension was considered primary in most works for about 40 years. In 199os Ch. Boettrich reverted to the idea of the primary nature of the long recension. That was argued by other scholars, for instance, by A. Orlov. Concerning the original language, most of the scholars considered it to be Greek; however N. Meshcherskii believed that it was Hebrew. See, for instance: The Book of the Secrets of Enoch, ed. R.H. Charles, Oxford, 1896; Соколов, Славянская Книга Еноха, Pt 2; Vaillant, Le livre des secrets d'Hénoch, esp. pp. XIII-XXIV; Н. Мещерский, "К истории текста Славянской Книги Еноха," Византийский временник, 24 (1964), pp. 91-108; Ch. Böttrich, Weltweisheit. Mehscheitsethik.Urkult (wUNT, 2:50), Tübingen, 1992, pp. 82-94; A. Orlov "Melchizedek legend of 2 (Slavonic) Enoch," JSJ, 31/1 (2000), pp. 23-38, and others.

For instance, N. Schmidt was the first to suppose 2 translations: N. Shmidt, "The two recensions of the Slavonic Enoch," JAOS, 41 (1921), pp. 307-312; later A. de Santos Otero reverted to this idea: A. de Santos Otero, "Libro de los Secretos de Henoc (Henoc eslavo)," in Apocrifos del Antiguo Testamento, vol. 4, Madrid, 1984, pp. 147-202, esp. pp. 147-156. 
two different translations could have the same hapax legomena. One of them is the word iacosopue (часовериe) chasoborie in the following context (according to the short recension): 7.8 [15.3] ${ }^{13}$ часшворие $\lambda$ 'Бтовноє слйце скАзаєть časoborie letovnoe slnce skazaetb, where it might have been a translation from the Greek

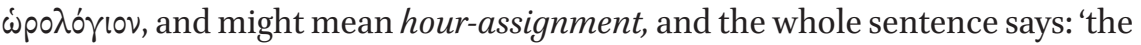
sun indicates hour-assignment in the year'. Some other hapax legomena are: 35.7 [70.6] раждєл' 'мия raždelěnie 'grief, sorrow', 30.7 [63.3] прєзорьствити prezorstviti 'to become haughty'.

We do not have the Greek original of the Slavic text, but even so, we can explain some points in the Slavonic text that have been preserved as possible translation errors. And again, they are almost the same in both recensions. One of them can be found in the fragment where the Lord's intention to send down the flood upon earth is narrated; here we read: 18.2 [35.1] и шставлю моужа прав-

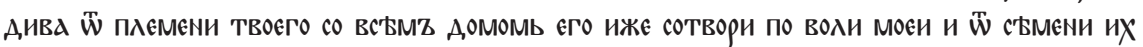

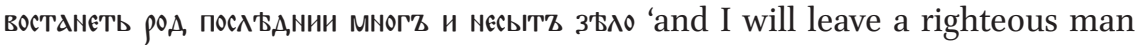
from your tribe, with all his house who will act in accordance with my will, and from their seed will arise another generation, the last [one], big [one] and very (extremely) rapacious/insatiable (?!)', the word necытZ nesytz rapacious/insatiable sounds strange in the context where it is said that this generation will receive the books written by Enoch and those books 'will be recounted to that generation, and they will be glorified in the end more than at the first'. So it might have been a translation error based on the similarity of the Greek words $\ddot{\alpha} \pi \lambda \varepsilon \tau 0 \varsigma$ uncountable, immeasurable and $\ddot{\alpha} \pi \lambda \eta \sigma \tau \circ \varsigma$ rapacious. So the Greek text might have had a different meaning primarily 'and from their seed will arise another generation, the last [one], numerous [one] and absolutely immeasurable'. The long recension, in this case, seems to have re-interpreted the doubtful reading, and so we have: '...another generation, the last [one], big [one], but from them many will be very rapacious/ insatiable'.

One more piece of evidence for one single translation is the existence of a number of readings that can be explained as a result of a modification that took place in Slavonic, but not in Greek (here we can speak about possible misreading, misunderstanding, reinterpreting, etc.). One of the most striking examples is the following: in the story of the creation we read:



ИзЫА, АРХАСС ТВРZА,Z

ТАЖЕКЬ И ЧРЬMЕн З'ВАO tion, and the numbers in brackets indicate the chapter and the verse in Andersen's translation. 
izide aruxazz s tverdiju

tiažekъ i černz zělo

'and Arukhaz came out, hard, heavy and very black' izide arxasz tvrzdz

tiažekъ i črbmen zělo

'and Arkhas came out, solid, heavy and very red'

At least, the variants we have in long recension can be explained as a re-interpreting of a 'strange' place in the short one.

The appearance of these two variants black and red cannot be explained in Greek, which has two totally different words in this case ( $\mu \dot{\varepsilon} \lambda \alpha \varsigma$ and $\dot{\varepsilon} p u \theta p o ́ s)$, but it is easy explicable in Slavonic, which had very similar words ipznz črnъ black and чрымьнz črmsnъ red, which can easily be confused.

[The Slavic с твердию $s$ tverdiju is a combination of preposition with a noun in Instrumental case, which can have the meaning of an adverbial modifier, so it can be translated as 'hard'. However, it can also be understood in a different, more literal way: $s$ means 'with', and the first meaning of $t v e r d b$ ( $t v r d b$ ) is 'firmament', in this meaning, for instance, it was used in Slavic as a translation of Greek $\tau \dot{0} \sigma \tau \varepsilon \rho \tilde{\varepsilon} \omega \mu \alpha \alpha$ (Gn.1.8 etc.), and so the phrase can be translated as 'Arukhaz came out with firmament, heavy and very black'.]

And finally, one more peculiarity of the Slavic text: it has many places where the meaning is not quite clear, or what Slavists call temnye mesta (lit. 'dark places', i.e. obscure places). One of them can be found in the very beginning of the story: when the angels who ascend Enoch are described, it is literary said

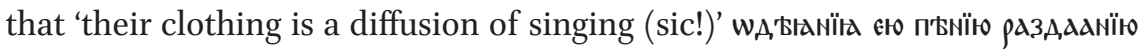
odějania eju pěniju razdajaniju, it is important to emphasize that both recensions in this case include this strange 'singing'. The existence of the same obscure places as this in both resensions, to my mind, also suggests one single translation. Concerning this particular place, it is worth pointing out that most translations are based on a conjectural reading, which reads п'亡нa pěna 'foam' instead of п'Њниє pěnie 'singing', so a possible translation in this case is 'their clothing is a diffusion of foam' $].{ }^{14}$ But if we do not use a conjectural reading, the place seems obscure (for instance, F. Andersen considered it to be 'incorrigibly corrupt' $).{ }^{15}$

14 Vaillant, Le livre des secrets d'Hénoch, p. 3; A. Pennigton, "2 Enoch," in The Apocryphal Old Testament, ed. H.F.D. Sparks, Oxford, 1984, pp. 321-362, here p. 329. F. Andersen leaves 'singing', but says at the same time that, although singing is a common theme in this book... it seems out of place at this point, where the whole interest is in the appearance of the men, and, especially, their clothing Andersen, "2 (Slavonic Apocalypse of) Enoch," p. 107 . Andersen, “2 (Slavonic Apocalypse of) Enoch," p. 106. 
However, I do not think we need to assume that there is a corruption of the text here, especially because, on one hand, all the manuscripts except one $\left(\mathrm{B}^{2}\right)^{16}$ gives the same reading - 'singing'; such 'unanimity' among the manuscripts is very rare in Slavonic Enoch (in most obscure places the manuscripts vary greatly), and because in Slavic languages the word 'foam' was never homonymous in form to 'singing', so this lectio deficilior can be considered to be primary in the Slavonic translation. In my article dedicated to a detailed study of this place, I tried to show that 'singing' might have been an authentic reading, and that we can shed light on this obscure place without conjectural readings. ${ }^{17}$

It is not possible to present all the argumentation here without becoming distracted from the main point of this paper, so I will merely say that the analysis was based on a consideration of different meanings of the Slavic word pernie 'singing' that we find in other Slavonic texts, and a comparison of this usage with the Greek and Hebrew words to which the Slavonic one corresponds in translated Slavonic texts (mostly Biblical ones). Such parallels between the Slavic word and the corresponding Greek and Hebrew words can explain the appearance of the Slavic pernie in this context, and makes the place quite 'clear' and 'understandable'. I needed this example here as an illustration of common lectio deficilior in both recensions that is shared by almost all the manuscripts.

To sum up, common hapax legomena, common translation errors, related readings which can be explained in Slavic and not in Greek, common 'obscure' places - all these witnesses seem sufficient for us to claim that there was only one translation and not two. Even if we assumed that the second translation was not an entirely new one, but was made on the basis of the existing one (i.e. the 'first' translation was 'corrected' and enlarged using a long recension that existed in Greek), we could explain the same hapax legomena in both recensions, but we could not explain why they have the same obscure places and translation errors, which should have been 'corrected' or 'clarified' according to the Greek text. And, of course, we could not explain readings like ypznz črnz 'black' and чрьмьнъ črmьnъ 'red', which demonstrate a strong verbal dependence between both recensions in Slavic, and not in Greek either.

Thus, in my opinion, deciding possible origins of recensions of a translated Slavonic text we should look for a 'cluster' of features that all together can speak for one or two/several different translations.

$16 \mathrm{~B}^{2}$ is the latest copy, and it often has a 'clearer' reading that is obviously of a secondary nature when the rest of the manuscripts have something more complicated.


Труды Отдела древнерусской литературы, vol. 53, St Petersburg, 2003, pp. 3-11. 
One of the most complicated areas when attempting to describe the textual history of a Slavonic translation is to determine where, when and into which Slavic dialect the translation was primarily made (and sometimes from which language, as well).

And it might be a problem, because the language of the Apocryphon can be "quite good literary language" which makes it difficult to say where and when the translation was made.

Again, I can give The Tale of Blessed Zorobabel as an example.

Despite its tripartite nature, the text of The Tale of Blessed Zorobabel is characterised by identical linguistic features. I agree with Sobolevskii that its language is quite good Church Slavonic, ${ }^{18}$ which makes it quite difficult to identify when and where the translation was made. The Church Slavonic forms fully predominate in phonetics, in grammar (morphology and syntax), and vocabulary.

Although Sobolevskii ${ }^{19}$ also remarked that the language of the Apocryphon had some West-Russian features, we did not find any such peculiarities. There are some things that can be regarded as West-Russian, but all of them are of an ambiguous nature: some forms are not Church Slavonic, but they can show the East Slavic origin in general, not West Russian in particular (for example, Part. Pres. Act. (78) pєка from рєчи, ${ }^{20}$ or the spelling 3 of the preposition cz), or they are possible in both Church Slavonic and West Russian as opposed to Old Russian (like the ending - ыи of the adjectives or the suffix - cא - of the adjectives, or the forms with the second palatalization of velars, the correct use of Vocativus).

The provenance of the Apocryphon is unclear, but perhaps something can be said about when it was translated. There are some features that might show its early origin. Dualis is used correctly: (51) шчи его зрита на ню,

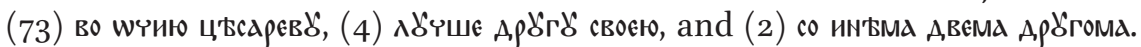
The Tale displays many short forms of adjectives (not only in Nom., but also


перски, etc. There are also some verb forms which might be interpreted not only as Aorist, but Supine as well: (58) АОсАГШи рб̆кою своєю и снат венєць 3

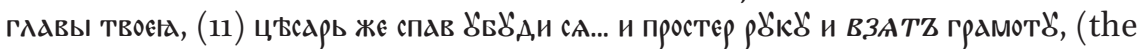
conjunction $\boldsymbol{n}$ might be secondary); and primarily Supine in the following phrase, too (as we have Gen. after the transitive verb) (78) А, и и, єТ А, ВААти

18 А.И. Соболевский, Переводная литература Московской Руси XIV-XVII веков, St Petersburg, 1903, p. 400.

19 Ibid.

20 А.И. Соболевский, Лекиии по истории русского языка, Moscow, 1907, p. 99. 
домб вожиА. The use of the short forms of adjectives, dualis, and possibly Supine might speak for the quite early translation. However, they are not decisive, for they also can be explained by the "good quality" of the Old Church Slavonic used by the translator.

Another series of questions that can be associated with the textual history of Slavonic Apocrypha has to do with their special nature. Given that they are translations, they can prevent us from solving certain problems because of the absence of the original. And this absence of an original has made the Slavonic Apocryphon one of the important (in some cases virtually unique) pieces of evidence for this original. Thus, it makes the work of the researcher extremely difficult and crucial when it refers to the decision which one of the different readings we find in the copies can claim to be primary.

Slavonic Apocrypha sometimes contained information that was totally unknown to the scribes, so it is possible that all the copies have "suffered" from a misunderstanding of this information, thus none of them can be claimed to be $100 \%$ primary over any of the others. ${ }^{21}$

To sum up, the philological approach to the textual history of Slavonic Apocrypha seems to ask us to be extremely careful and meticulous with all the information we can glean from the text, and to try to make, as far as possible, a comprehensive/thorough analysis of all the data we have before reconstructing the textual history of the text in question and preparing its editions.

L. Navtanovich, "The Second Enoch and The Tale of the Blessed Zerubbabel: two different examples of Old Testament Slavonic Apocrypha," Journal for the Study of the Pseudephigrapha, 19.2 (2009), pp. 109-126. 